\title{
Trend and Growth Pattern of Road Infrastructure in India in General and Karnataka in Particular
}

\author{
*Lokesha M.N \& **Dr.Mahesha M \\ Associate Professor, DOS in Economics and Cooperation, UOM, Mysore \\ Assistant Professor, Department of Economics, Government First Grade College, Channarayapatna, Hassan \\ District (Research Scholar, DOS in Economics and Cooperation, UOM, Mysore)
}

\begin{abstract}
Road network provides the arterial network to facilitate, transport, trade economic development and social integration. It facilitates specialization, extension of markets and exploitation of economies of scale. It is used for the smooth conveyance of both people and goods. Transportation by road has the advantage over other means of transport because of its easy accessibility, flexibility of operations, door-to-door service and reliability. Consequently, passenger and freight movement in India over the years have increasingly shifted towards roads from other means of transport. The economy of India is predominantly agrarian in nature. For the development of agriculture, the timely availability of inputs to the farm fields and timely marketing of produce especially perishable products are very much required which are only possible through the improved connectivity. Therefore, Road transport network is one of the most vital of all physical infrastructures. While the demand for expansion of transport generally derives from the needs of the other sectors of the economy, to an extent, the transport sector also acts as a leading factor in stimulating socio-economic development.
\end{abstract}

\section{INTRODUCTION}

Infrastructure is one of the important factors that drive the economic growth of a country. Good infrastructure is the basic requirement for any production process to work efficiently. Infrastructure itself may not be the part of the production process, but is important for the services it provides. It is an important input to the production process and raises the productivity of other sectors. Infrastructure connects goods to the markets, workers to industry, people to services and the poor in rural areas to urban growth centers. Infrastructure lowers costs, enlarges markets and facilitates trade. Thus, infrastructure provides services that support economic growth by increasing the productivity of labor and capital thereby reducing the costs of production and raising profitability, production, income and employment. Among all infrastructures road infrastructure is one of important infrastructure for economic development. It facilitates specialization, extension of markets and exploitation of economies of scale. It is used for the smooth conveyance of both people and goods. Transportation by road has the advantage over other means of transport because of its easy accessibility, flexibility of operations, door-to-door service and reliability. Consequently, passenger and freight movement in India over the years have increasingly shifted towards roads vis-a-vis other means of transport. In 2009-10, the road network in the country carried 85.2 per cent of the total passenger movement by roads and railways put together. Similarly, the corresponding figure for freight movement by roads was 62.9 percent.

\section{IMPORTANCE OF ROAD INFRASTRUCTURE IN AGRICULTURE}

The economy of India is predominantly agrarian in nature.India has experienced strong economic growth in recent years fueled by a booming services sector and increased industrial production. However, agriculture continues to remain the mainstay of the Indian economy engaging nearly 58 percent of the workforce and contributing to 16 percent towards the Gross Domestic Production (GDP). India has a dominant position in world agriculture, with the second largest arable land bank in the world and ranking in the top three producers of rice, wheat, coarse grains, fruits and vegetables, tea, coffee, and jute. India also has some of the largest livestock populations, which combined with the large farming sector help Ensures that agri-business remains the overwhelming contributor to the economy From both a monetary and employment perspective.For the development of agriculture, the timely availability of inputs to the farm fields and timely marketing of produce especially perishable products are very much required which are only possible through the improved connectivity. Therefore, transport network is one of the most vital of all physical infrastructures. While the demand for expansion of transport generally derives from the needs of the other sectors of the economy, to an extent, the transport sector also acts as a leading factor in stimulating socio-economic development. From the rural perspective, among the various modes of transportation road transportation is the most important transport infrastructure in the country. Road infrastructure provides the basic transport infrastructure in rural areas for bringing the majority of the people who are living in far-off villages into the mainstream of the economy by 
connecting them with rest of the country. As indicated earlier, the development of roads affects agriculture directly by enlarging the areas under cultivation. There is a two-fold relation between road development and increased agricultural products. Easy transport of manures, good seeds and better agricultural equipment, pesticides is made possible in time due to easy road transport. Better roads neutralise locational disadvantages in farming. Road development also prompts a change in the pattern of agricultural production by diversion of cultivation from food crops to commercial crops. Paucity of good roads in rural areas compels the cultivator to dispose of his produce to the village money lender at cheap prices. Good roads would open up the urban markets to the cultivator which would facilitate marketing of his product at higher prices. Moreover, bad roads are responsible for higher cost by transportation which increase the cost of marketing. A good road system also aids agriculture indirectly by breaking up the isolation of villages, spreading education and creating a general sense of awakening. The rural industries like dairy farming, bee-keeping, poultry farming, and sericulture. etc., can be developed as subsidiary industries to supplement their income in their spare time.Development of small scale and cottage industries becomes possible in rural areas due to the close road contact with their urban markets and the availability of raw materials at cheap prices. The important role played by the roads is very much felt during the days of famines. It has been observed regarding some of the Indian famines that the food scarcity in an area was not due to total deficiency. But owing to the isolation from the surplus area. Further, road development would facilitate flow of food from surplus to deficit areas and also equalize the prices in different markets. For relieving unemployment and promoting economic activity, road construction is an important item of the State governments to be taken up 56 to 70 per cent of the road cost of the road construction is spent as wages.

\section{TRENDS IN ROAD NETWORK IN INDIA}

The total road length of the country increased significantly from 3.99 lakh km in 1951 to 54.02 lakhs $\mathrm{km}$ in 2014 and further to 54.72 lakh km in 2015, The break-up of road length as on 31st March 2014 and 2015 are given below.

\begin{tabular}{|c|c|c|}
\hline \multicolumn{3}{|c|}{ Table:1 Road length as on $31^{\text {st }}$ March 2015} \\
\hline & Length of road $(\mathrm{km})$ & Share in total road length \\
\hline National Highways & 97,991 & 1.79 \\
\hline State Highways & $1,67,109$ & 3.05 \\
\hline Other PWD roads & $11,01,178$ & 20.12 \\
\hline Rural Roads & $33,37,255$ & 61.0 \\
\hline Urban Roads & $4,67,106$ & 8.54 \\
\hline Project Roads & $3,01,505$ & 5.50 \\
\hline Total & $54,72,144$ & 100.00 \\
\hline
\end{tabular}

Figuer -1 : Road length (As on 31st march 2015

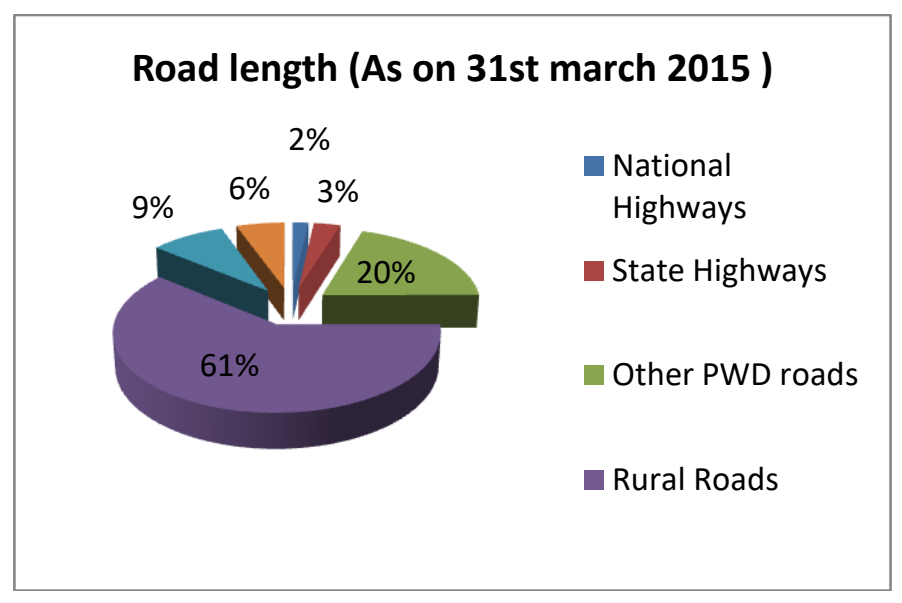

The largest share in the road network as on 31st March 2015 was that of rural roads (61\%). Other PWD Roads accounted for the second highest share (20\%), followed by Urban Roads by almost (9\%), Project Roads $(5 \%)$, SHs (3\%) and NHs (2\%). The five states with the largest road networks (excluding Jawahar Rozgar Yojana roads), viz. Maharashtra, Uttar Pradesh, Karnataka West Bengal and Assam accounted for about 43.04 $\%$ as on 31st March 2015 in the total road length of the country. 


\section{INTERNATIONAL COMPARISON OF ROAD NETWORK}

In the road infrastructure comparison with other countries reveals a mixed picture for India. As on 31st March 2015, India is doing well in terms of road density at $1.64 \mathrm{kms} / \mathrm{sq} . \mathrm{km}$ of area was higher than that of Japan $(0.91 \mathrm{~km} / \mathrm{sq} \mathrm{km})$, USA $(0.67 \mathrm{~km} / \mathrm{sq} \mathrm{km})$, China $(0.46 \mathrm{~km} / \mathrm{sq} . \mathrm{km})$, Brazil $(0.18 \mathrm{~km} / \mathrm{sq} \cdot \mathrm{km})$ and Russian Federation $(0.08 \mathrm{~km} / \mathrm{sq} \mathrm{km})$. The paved/surfaced road length in India was 59.61 per cent of the total road length which was much lower as compared to United Kingdom, Russia, China and USA.

Table-2 : International comparison of Road Network (2013)

\begin{tabular}{|l|r|r|}
\hline Country & Road density $(\mathrm{km} / \mathrm{sq} \mathrm{km})$ & Share of paved road (\%) \\
\hline India & 1.64 & 59.61 \\
\hline China & 0.46 & 67.89 \\
\hline Brazil & 0.18 & 13.0 \\
\hline Japan & 0.91 & $\mathrm{NA}$ \\
\hline Russian Federation & 0.08 & 70.54 \\
\hline UK & 1.73 & 100.00 \\
\hline U S A & 0.67 & 65.78 \\
\hline
\end{tabular}

Sources: For India - Transport Research Wing, Ministry of Road Transport \& Highways For all other countries - 'World Road Statistics 2015', published by International Road Federation, Geneva.

Figure-2: International comparison of Road Network

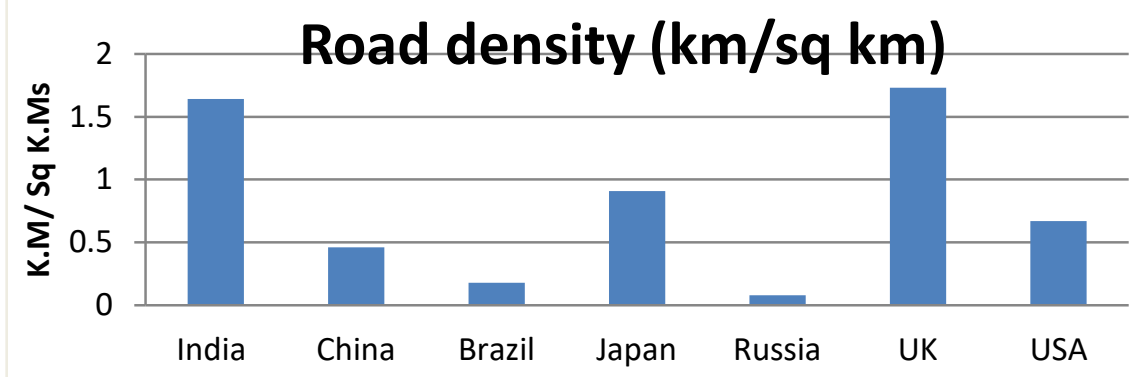

\section{Growth in Road Length}

The road transport infrastructure in India has expanded manifold during more than six decades after independence, both in terms of spread and capacity. Indian road network consists of National Highways, Expressways, state highways, major district roads, village roads etc. From 3.99 lakh kilometer as on 31st March 1951, the road length increased to 54.72 lakh kilometers as on 31st March 2015.

Table-3 : Road Network by Categories : 1951 to 2015

\begin{tabular}{|c|c|c|c|c|}
\hline Year & $\begin{array}{c}\text { Length of Roads } \\
\text { (Thousand k.ms ) }\end{array}$ & $\begin{array}{c}\text { Length of } \\
\text { National } \\
\text { Highways } \\
\text { (Thousand k.ms })\end{array}$ & $\begin{array}{c}\text { Length of State } \\
\text { Highways } \\
\text { (Thousand k.ms ) }\end{array}$ & $\begin{array}{c}\text { Share of surfaced } \\
\text { roads to total } \\
\text { roads (\%) }\end{array}$ \\
\hline 1951 & 400.0 & 22.2 & NA & 39.25 \\
\hline 1961 & 524.5 & 23.8 & NA & 50.10 \\
\hline 1971 & 915.0 & 24.0 & 56.8 & 43.50 \\
\hline 1981 & 1485.4 & 31.7 & 94.4 & 46.00 \\
\hline 1991 & 1998.2 & 33.7 & 127.3 & 51.30 \\
\hline 2001 & 3373.2 & 57.7 & 132.1 & 47.48 \\
\hline 2011 & 4690.3 & 70.9 & 163.9 & 49.92 \\
\hline 2015 & 5472.1 & 97.9 & 170.8 & 57.71 \\
\hline
\end{tabular}

Source: Basic Road Statistics published by ministry of road transport and highways 


\section{National highways}

National highways constitute the primary system of road transportation in India, These are main highways running through the length and breadth of the country connecting major ports, highways in neighboring countries, capitals of states and union territories and large industrial and tourist centers, and include roads required for strategic considerations. Out of the total length of 97,991 km as on 31st March 2015, as on $31^{\text {st }}$ March 2015 Uttar Pradesh accounted for the largest share (8.7\%) in the total length of NHs as on 31st March 2015, followed by Rajasthan (8.03\%), Maharashtra (7.2\%), Karnataka (6.6\%) and Madhya Pradesh (5.3\%). These five States accounted for about $35.75 \%$ of the total road length of NHs.

\section{State highways}

State highways (SH), together with Major District Roads (MDR), constitute the secondary system of road transportation in the country, and are administered and financed by state governments. SHs provide links with NHs, district headquarters of states and important towns, tourist centers and minor ports. The total length of SHs at present is about 1,67,109 kms (as on 31st March, 2015) Their length is about 4 per cent of the total road network and they carry 25 to 30 per cent of the total road traffic. As on 31st March, 2015, around 98.90\% of SH roads were surfaced out of total length of State Highways.

\section{Major District Roads}

Major District Roads run within districts connecting areas of production with markets, and rural areas with district headquarters and with SHs and NHs. Serving as links between rural and urban areas, SHs and MDRs contribute significantly to the rural economy and to the country's industrial development by enabling movement of raw materials and products from and to regional India. The development and maintenance of MDRs is the responsibility of state governments. Total length of major district roads is $11,01,178 \mathrm{~km}$ in March 2015.

\section{Rural Roads}

Rural roads cover Other District Roads and Village Roads and constitute the tertiary road network. They are a key component of rural development since they provide access to economic and social infrastructure and services, thereby generating increased agricultural income and productive employment opportunity in rural areas. Rural roads are used as an entry point for poverty alleviation. There is growing empirical evidence that links transport investments to the improved well-being of the poor. A study carried out by the International Food Policy Research Institute on linkages between government expenditure and poverty in rural India has revealed that an investment of Rs 100 million in roads lifts 16,500 poor persons above the poverty line (Fan, Hazell and Thorat, 1999). The total length of Rural Roads as on 31st March, 2015, were 33,37,255 kilometers.

Table-4 : State wise Total Road Length in different category (as on 31st march 2015)

\begin{tabular}{|l|r|r|r|r|r|r|}
\hline States/UT & $\begin{array}{l}\text { National } \\
\text { Highways }\end{array}$ & $\begin{array}{l}\text { State } \\
\text { Highways }\end{array}$ & $\begin{array}{l}\text { Other } \\
\text { PWD } \\
\text { Roads }\end{array}$ & $\begin{array}{l}\text { Rural } \\
\text { Roads* }\end{array}$ & $\begin{array}{l}\text { Urban } \\
\text { Roads }\end{array}$ & \multicolumn{1}{c|}{ Total } \\
\hline Andra pradesh & 4670 & 6485 & 35471 & 112787 & 13602 & 179022 \\
\hline Arunachala Pradesh & 2513 & 0 & 8393 & 11217 & 159 & 25362 \\
\hline Assam & 3784 & 2530 & 42332 & 255389 & 5096 & 326512 \\
\hline Bihar & 4701 & 4426 & 10128 & 175373 & 8823 & 206010 \\
\hline Chattisgarh & 3079 & 4374 & 24785 & 35048 & 11964 & 97534 \\
\hline Goa & 262 & 279 & 4501 & 8693 & 708 & 14624 \\
\hline Gujarat & 4971 & 18017 & 57854 & 62875 & 25762 & 182287 \\
\hline Haryana & 2307 & 2128 & 21749 & 6974 & 12553 & 46287 \\
\hline Himachal Pradesh & 2466 & 1466 & 30686 & 16552 & 2086 & 55593 \\
\hline Jammu \& Kashmir & 2593 & 131 & 9946 & 13127 & 1404 & 39096 \\
\hline Jharkhand & 2632 & 1358 & 7604 & 21150 & 652 & 42705 \\
\hline Karnataka & 6432 & 19721 & 49928 & 184918 & 42972 & 321808 \\
\hline Kerala & 1811 & 4341 & 27470 & 127985 & 24499 & 194854 \\
\hline Mahya Pradesh & 5184 & 10934 & 45911 & 177060 & 14752 & 288931 \\
\hline Maharashtra & 7048 & 40144 & 251787 & 267402 & 20687 & 608140 \\
\hline Manipur & 1746 & 715 & 9507 & 11121 & 182 & 24247 \\
\hline Meghalaya & 1204 & 751 & 7811 & 2807 & 215 & 13372 \\
\hline Mizoram & 1381 & 214 & 4786 & 2852 & 346 & 9831 \\
\hline
\end{tabular}


Trend and Growth Pattern of Road Infrastructure in India in General and Karnataka in Particular

\begin{tabular}{|l|r|r|r|r|r|r|} 
Nagaland & 1080 & 767 & 11371 & 23093 & 99 & 37176 \\
\hline Odisha & 4645 & 4109 & 12337 & 217919 & 19113 & 283692 \\
\hline Punjab & 2239 & 1133 & 6848 & 69170 & 15645 & 105368 \\
\hline Rajasthan & 7886 & 10941 & 87928 & 108159 & 27310 & 248156 \\
\hline Sikkim & 309 & 701 & 1415 & 4780 & 148 & $74 \mathrm{f} 50$ \\
\hline Tamil Nadu & 5006 & 11752 & 45538 & 165291 & 24592 & 261100 \\
\hline Telangana & 2687 & 2744 & 21093 & 70808 & 378 & 100251 \\
\hline Tripura & 577 & 1378 & 9639 & 24106 & 279 & 37384 \\
\hline Uttar Pradesh & 8483 & 3736 & 214131 & 80044 & 60551 & 415383 \\
\hline Uttarakhand & 2842 & 7543 & 24505 & 9104 & 4602 & 62945 \\
\hline West Bengal & 2910 & 3697 & 11872 & 169720 & 94544 & 395997 \\
\hline A \& N Islands & 331 & 279 & 492 & - & 141 & 1352 \\
\hline Chandigarh & 15 & 184 & 44 & - & 2692 & 2935 \\
\hline D \& N Haveli & 31 & 42 & 792 & - & - & 865 \\
\hline Daman \& Diu & 22 & 0 & 81 & 293 & 126 & 522 \\
\hline Delhi & 80 & 0 & 2462 & - & 29525 & 32067 \\
\hline Lakshadweep & - & 0 & 207 & - & & 214 \\
\hline Puducherry & 64 & 40 & 555 & 1438 & 892 & 3072 \\
\hline India & $\mathbf{9 7 9 9 1}$ & $\mathbf{1 7 0 8 1 8}$ & $\mathbf{1 1 0 1 1 7 8}$ & $\mathbf{2 4 3 7 2 5 5}$ & $\mathbf{4 6 7 1 0 6}$ & $\mathbf{4 5 7 2 1 4 4}$ \\
\hline
\end{tabular}

*Excluding JRY Roads

Source: Basic Road Statistics Published by Transport Research Wing, M/O Road Transport \& Highways

The five states with the largest road networks, viz. Maharashtra, Uttar Pradesh, Assam, Karnataka and West Bengal, accounted for about $43.04 \%$ of the total road length of the country during 2014-15.

\section{ROAD LENGTH IN RELATION TO AREA AND POPULATION}

As on march 2015, the total road length of the country, including JRY roads, per 100 square kilometers of area was 142.68 kilometers. Concurrently the total road length including Jry roads per lakh population is 387.57 kilometers as on $31^{\text {st }}$ march 2011. As on march 2011 the length of National Highways per 100 Square kilometers of area was 2.16 kilometers while the length of national Highways per lakh of population was 5.86kilometers.

Table-5 : Road length in relation to area and population in India (As on $31^{\text {st }}$ March 2015)

\begin{tabular}{|c|c|c|c|c|c|c|c|c|}
\hline \multirow[b]{2}{*}{ States } & \multirow[b]{2}{*}{$\begin{array}{c}\text { Total } \\
\text { Road } \\
\text { length** }\end{array}$} & \multirow[b]{2}{*}{$\begin{array}{c}\text { Area } \\
(\mathbf{k m} 2)\end{array}$} & \multirow[b]{2}{*}{$\begin{array}{c}\text { Populat } \\
\text { ion } \\
(2011) \\
\text { (in } \\
\text { Thousa } \\
\text { nds) }\end{array}$} & \multicolumn{2}{|c|}{$\begin{array}{c}\text { Road length (in } \\
\text { k.ms) }\end{array}$} & \multirow[b]{2}{*}{$\begin{array}{c}\text { Total } \\
\text { length } \\
\text { of } \\
\text { Natio } \\
\text { nal } \\
\text { High } \\
\text { ways } \\
\end{array}$} & \multicolumn{2}{|c|}{$\begin{array}{c}\text { National } \\
\text { Highways }\end{array}$} \\
\hline & & & & $\begin{array}{c}\text { per } 100 \\
\text { sq } \mathbf{k m} \\
\text { of area }\end{array}$ & $\begin{array}{c}\text { per one } \\
\text { lakh of } \\
\text { populat } \\
\text { ion }\end{array}$ & & $\begin{array}{c}\text { per } \\
100 \\
\text { sq } \\
\text { km of } \\
\text { area }\end{array}$ & $\begin{array}{c}\text { per } \\
\text { one } \\
\text { lakh } \\
\text { of } \\
\text { popu } \\
\text { latio } \\
\text { n }\end{array}$ \\
\hline $\begin{array}{l}\text { Andra } \\
\text { Pradesh* }\end{array}$ & 279273 & 275045 & 84666 & 101.537 & 329.853 & 4670 & 1.70 & 5.52 \\
\hline $\begin{array}{l}\text { Arunachala } \\
\text { Pradesh }\end{array}$ & 25362 & 83743 & 1383 & 30.2855 & 1833.84 & 2513 & 3.00 & $\begin{array}{r}181.7 \\
1\end{array}$ \\
\hline Assam & 326512 & 78438 & 31169 & 416.268 & 1047.55 & 3784 & 4.82 & 12.14 \\
\hline Bihar & 206010 & 94163 & 103805 & 218.78 & 198.459 & 4701 & 4.99 & 4.53 \\
\hline Chattisgarh & 97534 & 135191 & 25540 & 72.1453 & 381.887 & 3079 & 2.28 & 12.06 \\
\hline Goa & 14624 & 3702 & 1458 & 395.03 & 1003.02 & 262 & 7.08 & 17.97 \\
\hline Gujarat & 182287 & 196024 & 60384 & 92.9922 & 301.88 & 4971 & 2.54 & 8.23 \\
\hline Haryana & 46287 & 44212 & 25353 & 104.693 & 182.57 & 2307 & 5.22 & 9.10 \\
\hline $\begin{array}{l}\text { Himachal } \\
\text { Pradesh }\end{array}$ & 55593 & 55673 & 6857 & 99.8563 & 810.748 & 2466 & 4.43 & 35.96 \\
\hline $\begin{array}{l}\text { Jammu \& } \\
\text { Kashmir }\end{array}$ & 39096 & 222236 & 12549 & 17.5921 & 311.547 & 2593 & 1.17 & 20.66 \\
\hline Jharkhand & 42705 & 79714 & 32966 & 53.5728 & 129.543 & 2632 & 3.30 & 7.98 \\
\hline
\end{tabular}


Trend and Growth Pattern of Road Infrastructure in India in General and Karnataka in Particular

\begin{tabular}{|l|r|r|r|r|r|r|r|r|} 
Karnataka & 321808 & 191791 & 61131 & 167.791 & 526.424 & 6432 & 3.35 & 10.52 \\
\hline Kerala & 194854 & 38863 & 33388 & 501.387 & 583.605 & 1811 & 4.66 & 5.42 \\
\hline $\begin{array}{l}\text { Mahya } \\
\text { Pradesh }\end{array}$ & 288931 & 308245 & 72598 & 93.7342 & 397.988 & 5184 & 1.68 & 7.14 \\
\hline Maharashtra & 608140 & 307713 & 112373 & 197.632 & 541.18 & 7048 & 2.29 & 6.27 \\
\hline Manipur & 24247 & 22327 & 2722 & 108.599 & 890.779 & 1746 & 7.82 & 64.14 \\
\hline Meghalaya & 13372 & 22429 & 2964 & 59.6192 & 451.147 & 1204 & 5.37 & 40.62 \\
\hline Mizoram & 9831 & 21081 & 1091 & 46.6344 & 901.1 & 1381 & 6.55 & $\begin{array}{r}126.5 \\
\hline \text { Nagaland }\end{array}$ \\
\hline Odisha & 283692 & 155707 & 41947 & 182.196 & 676.311 & 4645 & 2.98 & 11.07 \\
\hline Punjab & 105368 & 50362 & 27704 & 209.221 & 380.335 & 2239 & 4.45 & 8.08 \\
\hline Rajasthan & 248156 & 342239 & 68621 & 72.5096 & 361.633 & 7886 & 2.30 & 11.49 \\
\hline Sikkim & 7450 & 7096 & 608 & 104.989 & 1225.33 & 309 & 4.35 & 50.82 \\
\hline Tamil Nadu & 261100 & 130058 & 72139 & 200.757 & 361.94 & 5006 & 3.85 & 6.94 \\
\hline Tripura & 37384 & 10486 & 3671 & 356.513 & 1018.36 & 577 & 5.50 & 15.72 \\
\hline Uttar Pradesh & 415383 & 240928 & 199,281 & 172.41 & 208.441 & 8483 & 3.52 & 4.26 \\
\hline Uttarakhand & 62945 & 53483 & 10117 & 117.692 & 622.171 & 2842 & 5.31 & 28.09 \\
\hline West Bengal & 395997 & 88752 & 91348 & 446.184 & 433.504 & 2910 & 3.28 & 3.19 \\
\hline $\begin{array}{l}\text { A \& N } \\
\text { Islands }\end{array}$ & 1352 & 8249 & 380 & 16.3899 & 355.789 & 331 & 4.01 & 87.11 \\
\hline Chandigarh & 2935 & 114 & 1055 & 2574.56 & 278.199 & 15 & 13.16 & 1.42 \\
\hline $\begin{array}{l}\text { D \& N } \\
\text { Haveli }\end{array}$ & 865 & 491 & 343 & 176.171 & 252.187 & 31 & 6.31 & 9.04 \\
\hline $\begin{array}{l}\text { Daman \& } \\
\text { Diu }\end{array}$ & 522 & 112 & 243 & 466.071 & 214.815 & 22 & 19.64 & 9.05 \\
\hline Delhi & 32067 & 1483 & 16753 & 2162.31 & 191.41 & 80 & 5.39 & 0.48 \\
\hline Lakshadweep & 214 & 32 & 64 & 668.75 & 334.375 & & 0.00 & 0.00 \\
\hline Puducherry & 3072 & 479 & 1244 & 641.336 & 246.945 & 64 & 13.36 & 5.14 \\
\hline $\begin{array}{l}\text { All India } \\
\text { Excluding } \\
\text { JRY roads) }\end{array}$ & 4572144 & 3287240 & 1210193 & 139.088 & 377.803 & 70934 & 2.16 & 5.86 \\
\hline & & & & & & & & \\
\hline
\end{tabular}

*Andrapradesh including Telangana. **Total road length Excluding JRY Roads

Source: Basic Road Statistics Published by Transport Research Wing, M/O Road Transport \& Highways

\section{ROAD INFRASTRUCTURE IN KARNATAKA}

Karnataka is the seventh largest state in India with a geographical area of 1,91,791 square kilometers. The state is well connected to its six neighboring states and other parts of India through 14 national highways it accounts for about six percent of the total national highways network in India. Its district centers are linked through 114 state highways. Total road length in Karnataka comprises of several national highways, state highways, important district roads, other districts roads, Z P roads and village roads. The total length of road at present is of the order of 2,39,055 kilometers in 2014-15. Of which 4,688kilometer is national highways 18,921 kilometers is state highways, 49683 kilometers is major district roads, 8,366 kilometers is municipal roads and $1,55,545$ kilometers is village roads (public works, ports and inland water department, 2015). On an average, about 80 kilometers of road exists per every 100sq Km of geographical area. The national standard envisages a road network of about $100 \mathrm{~km}$ per $100 \mathrm{sq} \mathrm{km}$ of area. Thus, the state as a whole is lagging behind the suggested norms. Year wise road network connectivity details shows in following table.

\section{TRENDS IN ROAD NETWORK IN KARNATAKA}

As on 2014 March, the state had a total 75,171 Km. with 4,668 Km. National Highways, 20,577 K.M. State Highways and 49,906 Km. Major District Roads. It comprised 69,813 Km. Cement and Black top roads, $3552 \mathrm{Km}$. Macdam roads and 1,806 Km. Kaccha roads All the National Highways and large extent of State Highways (98.7\%) and 90\% of Major District Roads are covered with blacktop.

\section{NATIONAL HIGHWAYS:}

The National Highways are very important highways which connect Metropolitan cities, State capitals, Ports etc. throughout the country. The length of the National Highways in 2015 was $6,540 \mathrm{~km}$. National 
Highways are maintained and developed by respective zones with funds from Government of Karnataka, National Highway Authority of India and Ministry of Road Transport \& Highways, Government of India.

\section{STATE HIGHWAYS:}

State Highways are important joining links connecting the district headquarters with the state capital and interconnecting links between the National Highways in the state. As on 31-03-2013, the number of state highways has increased to157 and the total road length has gone up to 20748.75 , controlled by the P.W.D. department.

\section{MAJOR DISTRICT ROADS:}

As on March 2008, there was 49,958.93 km. roads of this category in the State, maintained by the PWD. Tumakuru district with 3,761 km was ranked first. Bengaluru district (Urban) with $656.05 \mathrm{~km}$. was at the bottom. Apart from this, there were $8,366 \mathrm{~km}$. of Municipal roads in city/ town limits maintained by corporations, city Municipal corporations etc., As on march 2015, $49683 \mathrm{~km}$. MDR roads existed in the State.

\section{RURAL ROADS:}

Rural roads are key components of rural development. Rural roads comprise Other district roads and village roads. Improvement of Roads and their maintenance is the responsibility of the Zilla Panchayats since 1987. The technical supervision is the responsibility of Rural Development and Panchayat Raj Department. Improvement of Roads and their maintenance is being done through the district sector Roads \& Bridges schemes, Employment generation schemes and Pradhan Manthri Gram Sadak Yojana etc., Accordingly, at the end of March 2015, the total 1,55,545 km. of Rural roads. The Rural roads are developed and maintained under Prime Minister's Grama Sadak, NABARD, Chief Minister's Rural Road Development Rural Communication, Our village-Our Road and such other programmes. Roads maintained by Taluk Development Board, Irrigation, Forest, Corporation, City Municipality, Town Municipality and Town Panchayat are in the State.

Table-6 : Road Length in Karnataka (in KMs)

\begin{tabular}{|c|r|r|r|r|r|r|}
\hline Year & $\begin{array}{c}\text { National } \\
\text { Highways }\end{array}$ & $\begin{array}{c}\text { State } \\
\text { Highways }\end{array}$ & $\begin{array}{c}\text { Major District } \\
\text { Roads }\end{array}$ & \multicolumn{1}{c|}{$\begin{array}{c}\text { Municipal } \\
\text { Roads }\end{array}$} & $\begin{array}{c}\text { Other Road } \\
\text { including } \\
\text { Village Roads }\end{array}$ & All roads \\
\hline $1999-00$ & 3728 & 9829 & 28247 & 8366 & 98419 & 148589 \\
\hline $2000-01$ & 3728 & 9829 & 28247 & 8366 & 104034 & 154204 \\
\hline $2001-02$ & 3728 & 9829 & 28247 & 8366 & 104034 & 154204 \\
\hline $2002-03$ & 3728 & 9829 & 28247 & 8366 & 104034 & 154204 \\
\hline $2003-04$ & 3967 & 9590 & 28247 & 8366 & 94034 & 144204 \\
\hline $2004-05$ & 3973 & 17228 & 30760 & 8366 & 115574 & 175901 \\
\hline $2005-06$ & 3958 & 17405 & 32572 & 8366 & 146713 & 209014 \\
\hline $2006-07$ & 3958 & 18642 & 37671 & 8366 & $147212^{*}$ & 215849 \\
\hline $2007-08$ & 3958 & 20739 & 47763 & 8366 & $147212^{*}$ & 228038 \\
\hline $2008-09$ & 3982 & 20905 & 47836 & 8366 & $147212^{*}$ & 228301 \\
\hline $2009-10$ & 4490 & 20528 & 50436 & 8366 & $147212^{*}$ & 231032 \\
\hline $2010-11$ & 4490 & 20528 & 50436 & 8366 & $177212^{*}$ & 231032 \\
\hline $2011-12$ & 4490 & 20770 & 49959 & 8366 & $148412^{*}$ & 231997 \\
\hline $2012-13$ & 4490 & 20770 & 49959 & 8366 & $148412^{*}$ & 231997 \\
\hline $2013-14$ & 4688 & 20773 & 49683 & 8366 & $155545^{*}$ & 239055 \\
\hline $2014-15$ & 6540 & 18921 & 49683 & 8366 & $155545^{*}$ & 239055 \\
\hline
\end{tabular}

Source: Public Works Department \&RDPR Department* Includes ODR \& Village Roads.

\section{DISTRICT WISE DETAILS OF ROAD LENGTH IN KARNATAKA}

The state road network consist of National Highways (NH), State Highways (SH), Major district Roads, municipal rods and other roads including village connectivity roads. The road development works woks in the state are carried out by multiple agencies, which include public works department of the state government, local governments such as Zilla panchayath and its wings and in urban areas, the city corporations, city municipal corporations etc. The state divided in to 30 districts. In the state, the average length of PWD roads (viz; NH, SH\&MDR) per 100 square kilometers is 39.34 kilometer. However, the distribution of the roads between the districts, and within the districts is not at all balanced. Here is the table showing the district wise details of road length in Karnataka. 
Table-7: District wise details of Road length in Karnataka (2014-15)

\begin{tabular}{|l|r|r|r|r|}
\hline \multirow{2}{*}{ Name Of The District } & \multicolumn{2}{|c|}{ Road Length (in K.Ms } & \multirow{2}{*}{ Total Road Length } \\
\cline { 2 - 3 } & \multicolumn{1}{|c|}{ NH } & \multicolumn{1}{c|}{ SH } & \multicolumn{1}{c|}{ MDR } & \\
\hline Bagalkote & 166.91 & 814.56 & 1586.20 & 2567.67 \\
\hline Bengalore & 147.00 & 116.70 & 725.79 & 989.49 \\
\hline Bengalore Rural & 205.00 & 207.60 & 666.80 & 1079.40 \\
\hline Belagavi & 201.00 & 2351.81 & 3045.97 & 5598.78 \\
\hline Ballari & 394.73 & 929.91 & 1804.54 & 3129.18 \\
\hline Bidar & 209.81 & 652.22 & 869.38 & 1731.41 \\
\hline Chamarajanagara & 201.24 & 319.77 & 995.21 & 1516.22 \\
\hline Chikkaballapura & 148.00 & 263.88 & 928.04 & 1339.92 \\
\hline Chikkamagalore & 267.61 & 535.61 & 1632.82 & 2436.04 \\
\hline Chitradurga & 286.70 & 439.51 & 2096.10 & 2822.31 \\
\hline Dakshina Kannada & 310.40 & 455.80 & 774.85 & 1541.05 \\
\hline Davanagere & 187.42 & 731.05 & 1602.50 & 2520.97 \\
\hline Dharvad & 191.90 & 484.41 & 1389.50 & 2065.81 \\
\hline Gadag & 103.57 & 683.42 & 1179.19 & 1966.18 \\
\hline Kalaburgi & 279.14 & 1333.11 & 1246.35 & 2858.60 \\
\hline Hassan & 252.16 & 996.03 & 3131.36 & 4379.55 \\
\hline Haveri & 157.90 & 588.14 & 1838.62 & 2588.66 \\
\hline Kodagu & 62.19 & 476.31 & 855.80 & 1394.00 \\
\hline Kolar & 137.40 & 305.52 & 1224.50 & 1667.42 \\
\hline Koppal & 162.69 & 673.20 & 1449.17 & 2285.06 \\
\hline Mandya & 206.21 & 351.67 & 2881.87 & 3439.75 \\
\hline Mysore & 237.63 & 591.68 & 2603.09 & 3432.40 \\
\hline Ramanagara & 93.00 & 273.66 & 1553.60 & 1920.26 \\
\hline Raichur & 163.00 & 850.52 & 1506.81 & 2520.33 \\
\hline Shivamoga & 398.10 & 953.92 & 2115.83 & 3467.85 \\
\hline Tumkur & 390.45 & 687.38 & 3787.75 & 4865.58 \\
\hline Udupi & 218.40 & 298.51 & 790.08 & 1306.99 \\
\hline Uttara kannada & 359.32 & 1235.71 & 2038.56 & 3633.59 \\
\hline Vijayapura & 297.07 & 698.02 & 2402.51 & 3397.60 \\
\hline Yadagiri & 136.20 & 421.32 & 1205.87 & 1763.39 \\
\hline Karnataka & 6572.15 & 19720.95 & 49928.36 & 7622.46 \\
\hline & & & & \\
& & & & \\
\hline
\end{tabular}

Source: Statistical Handbook of Karnataka, Directorate of Economics and Statistics

The above table depict that Belagavi ranked $1^{\text {st }}$ plase in the total road length with the total road length of 5598.78 Kilometers of road and Bangalore, Kodagu and Udupi districs have comparatively lesser road networks.

\section{CONCLUSION}

The transport sector is an important component of the economy; impacting on development and the welfare of populations. Road transportation penetrates further into the nooks and cranny of the human environment than other means of transportation. The Government laid down a framework for accelerated growth through investments in infrastructure and integrated rural development including agriculture. While requirements of national highways are being taken care of by the Government of India, development and maintenance of other categories of roads basically rest with the state governments. Of particular concern does the situation in respect of secondary system comprise state highways and major district roads. By acting as linkages between the rural and urban areas, these roads contribute significantly to the rural economy as also to the industrial development of the country by enabling movement of industrial raw materials and products from and to the interiors of the country. The past experience shows that the states found it difficult to allocate the needed funds for the secondary roads. Further, due to expansion of the rural roads, traffic on the secondary network continued to rise. The deficiencies on these roads are also thus a matter of concern so as to reap the full benefit of investments in the rural roads infrastructure. Availability of adequate infrastructure in rural as well as urban areas is the sine qua non for economic development of a nation. Access to rural infrastructure has a strong positive association with rural economic development and strong negative association with incidence of poverty. 


\section{REFERENCES}

[1] Infrastructure Statistics -2014, Central Statistics Office, Ministry Of Statistics And Programme Implementation, Government of India, New Delhi.

[2] Karnataka Economic Survey, 2014-15

[3] Basic Road Statistics Of India,2014-15,Government Of India, Ministry Of Road Transport And Highways, Transport Research Wing, New Delhi.

[4] Ministry of Rural Development (2007). Rural Road, Development Plan: Vision 2025. New Delhi: Government of India.

[5] Fan, Shenggen, Peter Hazell and S K Thorat (1999), "Linkages between Government Spending, Growth and Poverty in Rural India", International Food Policy Research Institute, Washington, DC, USA.

[6] Karnataka Economic Survey, 2014-15, Government of Karnataka, Planning, Programme monitoring \& Statistics Department, March, 2015

[7] Statistical Handbook of Karnataka, Directorate of Economics and Statistics 